\title{
Analysis of Protocols of Bucal Hygienization in Patients in the Intensive Therapy Unit (ICU)
}

\section{Gleycielly da Mota Oliveira Souza ${ }^{1 *}$, Carolina de Lima Borges ${ }^{2}$, Rosa Natalia Rendall dos Santos Ratis ${ }^{1}$ and Vivian Kelly Leite Pedrosa ${ }^{1}$}

${ }^{1}$ Dentist-Surgeon, Faculdade Integrada de Pernambuco, Brazil

${ }^{2}$ Dentist-Surgeon, Resident of Cancer Care and Palliative Care, Instituto de Estudos Avançados da ASCES-UNITA, Brazil

*Corresponding author: Gleycielly da Mota Oliveira Souza, Dentist-Surgeon, Faculdade Integrada de Pernambuco, Rua Etelvino Souto Maior, NO. 55, Centro, CEP: 55730-000, Bom Jardim-PE, Brazil, Tel: +55-81-99654-2120

\begin{abstract}
Constant care should be adopted for the treatment of patients hospitalized in Intensive Care Units (ICUs). It is necessary to cover the proper oral hygiene habit given to the interrelationship between oral and systemic diseases, in the development of nosocomial pneumonia. Considering these deficiencies and elucidated problematizations, the present study aimed to evaluate the oral hygiene protocols in patients hospitalized in the Intensive Care Unit. National and international protocols and studies, published between 2000 and 2017, were analyzed regarding the hygiene process, the proposed method and the benefits obtained. The incorporation of the dentist surgeon into the ICU team is extremely necessary for the promotion of health and quality of life of critically ill patients. The regularization of a protocol of oral hygiene in patients of the intensive care unit, becomes relevant for the reduction of the incidence of pneumonia associated with mechanical ventilation, reduction of hospitalization time and consequently, for the promotion of oral comfort and quality of life.
\end{abstract}

\section{Keywords}

Intensive care units, Exposure to biological agents, Oral hygiene

\section{Abbreviation \\ ICU: Intensive Care Units}

\section{Introduction}

Patients hospitalized in Intensive Care Units (ICUs) should receive special and constant care, not only to treat the illness that led to hospitalization, but also to take care of other organs and systems that may implicate in their recovery and prognosis [1]. The necessary care should be fully evaluated, involving a multidisciplinary team, prioritizing the general well-being of the patient in intensive care [2].

Oral hygiene deficiency is common in these patients, who often remain open-mouthed due to orotracheal intubation. This promotes dehydration of the mucosa and leads to a decrease in salivary flow, providing a greater colonization of bacteria, which leads to the predisposition of infectious foci, as in the case of periodontal diseases [3]. A greater amount and differentiation of the dental biofilm can promote interactions between native bacteria and respiratory pathogens, contributing to the development of diseases [4].

In the intensive care unit, there is an interest in the possible relationship between oral health and systemic disease, especially regarding the development of pneumonia associated with mechanical ventilation [5]. Nosocomial pneumonia may develop from the bronchoaspiration of pathogens present in the buccal microbiota or from periodontal disease, by the hematological diffusion of pathogens present [6].

The presence of biofilm interferes with oral alterations present in the patient, such as caries, periodontal disease, pulp necrosis, among others. They affect both the therapy employed and the general state of the patient [7].

Citation: Souza GMO, Borges CL, Ratis RNRS, Pedrosa VKL (2019) Analysis of Protocols of Bucal Hygienization in Patients in the Intensive Therapy Unit (ICU). Int J Oral Dent Health 5:079. doi. org/10.23937/2469-5734/1510079

Accepted: February 07, 2019: Published: February 09, 2019

Copyright: (C) 2019 Souza GMO, et al. This is an open-access article distributed under the terms of the Creative Commons Attribution License, which permits unrestricted use, distribution, and reproduction in any medium, provided the original author and source are credited. 
Dental care, such as the correct oral hygiene protocol, should be performed in the ICUs by a trained dentist and a nursing team to help eliminate the potential microbiological reservoirs that compromise these patients [8].

The present study aimed to evaluate oral hygiene protocols in patients hospitalized in the Intensive Care Unit. Looking to know the care taken, such as the method of oral hygiene and materials used, instituted in the literature.

\section{Methods}

The present study deals with a review of the descriptive and qualitative literature using a narrative review of the literature. The search descriptors searched in Portuguese and English were: Intensive Care Unit, exposure to biological agents, oral hygiene method and oral hygiene protocols in the ICU. For the accomplishment of this study, protocols and national and international studies, on an unsystematic basis, on hospital odontology in the ICU, published between 2000 and 2017 were analyzed. The databases used in the research were: BIREME, SCIELO, MEDLINE. In which, the articles about the oral hygiene protocols were selected in patients under care in the Intensive Care Unit (ICU).

\section{Results/Discussion}

For this study we evaluated 8 protocols and studies reported in the literature and instituted in hospitals.
The solutions used and the proposed method were analyzed, as well as the benefits obtained with the results of the use of these protocols in oral hygiene.

According to a study carried out by Santos [3], in a pilot cross section, in which a protocol was instituted in the Central Hospital of the Brotherhood of Santa Casa de Mericórdia of São Paulo (Table 1). An enzyme solution based on lactoperoxidase, which is an enzyme present in human saliva, has been used. The results obtained showed a visual improvement of the inflammatory appearance of the gums, oral dryness, halitosis and the ease of removal of debris.

The choice of an enzymatic product is important, since the absence in its composition of an abrasive substance, such as alcohol, detergent and dye, prevents it from further damaging the compromised oral mucosa [9].

According to a study by Makabe [10], 150 adult patients of both sexes were admitted to the ICU of a Public Hospital in the city of São Paulo. The material was collected and analyzed, the presence of yeasts, filamentous fungi and bacteria was observed. An analysis of three products used in oral hygiene was carried out once a day for three consecutive days.

In the process of oral disease prevention, it is important to use the mechanical removal of the dental biofilm, which may or may not be associated with the use of chemical agents [11]. The daily use associated with

Table 1: Oral hygiene protocol with use of enzymatic solution based on lactoperoxidase.

\section{Solution}

Bioténe mouthwash-MS

2.2561.0003.001-6

\section{Protocol}

1) Putting on procedure gloves;

2) Separate the oral solution bioténe;

3) Put into the beaker a $10 \mathrm{~mL}$ doser;

4) Soak the rod in the solution;

-Pass on the tongue in the posteroanterior sense;

-Pass in the vestibules and cheeks posteroanterior sense;

-Pass the palate in the anterior-anterior direction;

-Apply to the buccal, lingual and occlusal surfaces of the teeth.

5) Aspirate the oropharynx during the procedure. For statistical analysis of the data collected from microorganisms found and from the IHOS, Chi-Square and Fisher's exact tests were used

Table 2: Evaluation of filtered water, chlorhexidine digluconate $0.12 \%$ and ethanolic extract of propolis $6 \%$ in oral hygiene of patients admitted to the ICU.

\begin{tabular}{|c|c|c|c|}
\hline & $\begin{array}{l}\text { Filtered water and } \\
\text { mechanical reduction }\end{array}$ & $\begin{array}{l}\text { Chlorhexidine digluconate } \\
0.12 \%\end{array}$ & Extract ethanolic of propolis to $6 \%$ \\
\hline Results obtained & $\begin{array}{l}\text { Reduced salivary flow and dry } \\
\text { lips. Reduced the isolation of } \\
\text { yeasts, filamentous fungi and } \\
\text { bacteria as a consequence } \\
\text { of the mechanical activity of } \\
\text { debris removal. }\end{array}$ & $\begin{array}{l}\text { Reduced salivary flow and } \\
\text { dry lips. Inhibited yeast } \\
\text { growth and reduced the } \\
\text { isolation of filamentous } \\
\text { fungi and bacteria in the } 3 \\
\text { days of sanitization. Yeast } \\
\text { isolates were sensitive } \\
\text { to a concentration of } \\
0.12 \% \text {. It inhibited the } \\
\text { production of proteinase and } \\
\text { phospholipase exoenzymes } \\
\text { and the production of fringes. }\end{array}$ & $\begin{array}{l}\text { Reduced salivary flow and dry lips. It } \\
\text { inhibited the growth of yeasts, did not } \\
\text { alter the isolation of filamentous fungi, } \\
\text { and greatly reduced the isolation of } \\
\text { bacteria. Yeast isolates were sensitive to } \\
\text { a concentration of } 20 \% \text {. Inhibited } 80.56 \% \\
\text { of the yeasts isolated to the concentration } \\
\text { of } 5 \% \text {. It inhibited the production } \\
\text { of proteinase and phospholipase } \\
\text { exoenzymes and the production of } \\
\text { fringes. }\end{array}$ \\
\hline
\end{tabular}


a dental hygiene protocol on dental biofilm provides a prevention of mechanical ventilation associated pneumonia-VAP [12].

The use of substances that reduce the contamination of the oral microbiota is important to avoid infections. The $0.12 \%$ Chlorhexidine Digluconate solution containing xylitol significantly reduced the prevalence of aerobic gram-positive cocci, responsible for the first phase of infection [13] (Table 2).

The antimicrobial activity of the $6 \%$ propolis ethanolic extract on different oral pathogens demonstrated in vitro antimicrobial activity, inhibition of cell adherence on glass surfaces and inhibited the formation of insoluble glycan [14]. In studies by Gebara [15], show that the $6 \%$ propolis ethanolic extract shows good antimicrobial activity, mainly against periodontal bacteria and inhibition of bacterial growth.

Miranda \& Montenero [16], performed a dental intervention in the ICU of a hospital in Brasília-DF, in a 86-year-old patient. The elimination of the presence of dental biofilm and supragingival calculus was done by scraping, associated with prophylaxis made with dental brush and prophylactic paste. In addition, tooth brushing with acidified phosphate fluoride at $1.23 \%$ was chosen to maintain the buccal cavity with a basic $\mathrm{pH}$, which is less harmful to dental structures. Associated with tongue hygiene with the $0.12 \%$ chlorhexidine gluconate solution by gauze soaked and fixed in a needle holder and tongue cleaners. The procedures were performed during 6 consecutive days, after this period a significant improvement of the patient's oral condition was observed.

In a study conducted by Amaral [17], in which the questionnaires were carried out by the multidisciplinary team regarding the methods and protocols of biofilm control used as an oral hygiene protocol in the ICU. As the most frequent method used, $67 \%$ answered that it was the use of gauze moistened in antiseptic on mucous membranes, tongue, cheek and teeth. Among the available antiseptics, chlorhexidine digluconate was the solution most frequently mentioned by professionals. It was verified that the methods approached were not adequate.

The influence of oral health on the systemic condition, and vice versa, shows the need for the dental surgeon to be part of the multidisciplinary teams in the Intensive Care Units. Poor oral hygiene, as well as the lack of clinical dental practices, professional adaptation and neglect of oral health by patients themselves and health professionals, poses risks to patient's systemic health. The performance of dentists trained in ICUs is fundamental to promote the health and quality of life of critical patients [18].

\section{Conclusion}

The incorporation of the dental surgeon into the multidisciplinary team of intensive care units is of paramount importance, as oral affections are sources of systemic aggravation and proliferation of infectious processes, which is a good prevention strategy. Regarding the protocols, there is still controversy in the literature about which protocol is the best, the product to be used and the frequency to be performed. However, the institutionalization of an oral hygiene protocol in intensive care unit patients is relevant for reducing the incidence of pneumonia associated with mechanical ventilation, reducing hospitalization time and, consequently, for promoting oral comfort and quality of life.

\section{References}

1. Faiçal AMB, Mesas AE (2008) Cuidados com a saúde bucal em pacientes hospitalizados: Conhecimento e práticas dos auxiliaries de enfermagem. Revista Espaço para a Saúde 10: 1-6.

2. Araújo RJG, Vinagre NPL, Sampaio JMS (2009) Avaliação sobre a participação de cirurgiões-dentistas em equipes de assistência ao paciente. Acta Scientiarum Health Sciences 31: 153-157.

3. Santos PSS, Mello WR, Wakim RCS, Paschoal MAG (2008) Uso de solução bucal com sistema enzimático em pacientes totalmente dependentes de cuidados em unidade de terapia intensiva. RBTI 20: 154-159.

4. Willis PJ (1965) The role of dentistry in the hospital. J Am Dent Soc Anesthesiol 12: 40-44.

5. Fernandes AT, Fernandes MOV, Ribeiro Filho N (2000) Infecção hospitalar e suas interfaces na área da saúde. São Paulo: Atheneu 516-555.

6. Nascimento ERP, Trentini M (2004) O cuidado da enfermagem na unidade de terapia intensiva (UTI): Teoria humanística de Paterson e zderad. Rev Lat Am Enfermagem 12: 250-257.

7. Pasetti LA, Carneiro Leão MT, Araki LT, Albuquerque AMN, Ramos TMB, et al. (2013) Odontologia hospitalar: A importância do cirurgião dentista na unidade de terapia intensiva. Rev Odontologia 13: 211-226.

8. Miranda AF, Lia EM, Carvalho TM, Piau CGBC, Costa PP, et al. (2016) Oral health promotion in patients with chronic renal failure admitted in the intensive care unit. Clin Case Rep 4: 26-31.

9. Tenovuo J (2002) Clinical applications of antimicrobial host proteins lactoperoxidase, lysozyme and lactoferrin in xerostomia: Efficacy and safety. Oral Dis 8: 23-29.

10. Makabe MLF (2015) Oral higiene with chlordexdine digluconate and ethanol extract of propolis in patients in the intensive care unit (ICU) of public hospital in São PauloBrazil.

11. Zanela NLM, Bijella MF, Rosa OP (2002) The influence of mouthrinses with antimicrobial solutions on the inhibition of dental plaque and on the levels of mutans streptococci in children. Pesqui Odontol Bras 16: 101-106.

12. Sona C, Zack JE, Schallom ME, Mcsweeney M, Mcmullen $\mathrm{K}$, et al. (2009) The impact of a simple, low cost oral care protocol on ventilator-associated pneumonia rates in a surgical intensive care unit. J Intensive Care Med 24: 5462 . 
13. Lima EF, Lima JB, Alves RL, Rocha MMNP, Rego RD, et al. (2014) Avaliação clínica do efeito de bochechos com digluconato de clorexidina $0.12 \%$ com e sem xilitol na contaminação de fios de sutura. Rev Bras Pesq Saúde 16: 59-66.

14. Koo H, Gomes BP, Rosalen PL, Ambrosano GM, Park YY, et al. (2000) In vitro antimicrobial activity of propolis and arnica montana against oral pathogens. Arch Oral Biol 45: 141-148.

15. Gebara ECE, Lima LA, Mayer MPA (2002) Propolis antimicrobial activity against periodontopathic bacteria. Braz J Microbiol 33: 365-369.
16. Miranda AF, Montenegro FLB (2010) Ação odontológica preventiva em paciente idoso dependente na unidade de terapia intensiva (UTI)-relato de caso. Revista Paulista de Odontologia 32: 34-38.

17. Amaral COF, Marques JA, Bovolato MC, Parizi AGS, Oliveira A, et al. (2013) Importância do cirurgião-dentista em unidade de terapia intensiva: Avaliação multidisciplinar. Rev Assoc Paul Cir Dent 67: 107-111.

18. Miranda AF (2017) The importance of oral health as integral part of the care given to intensive care unit patients. JOJ Nurse Health Care 1: 1-3. 